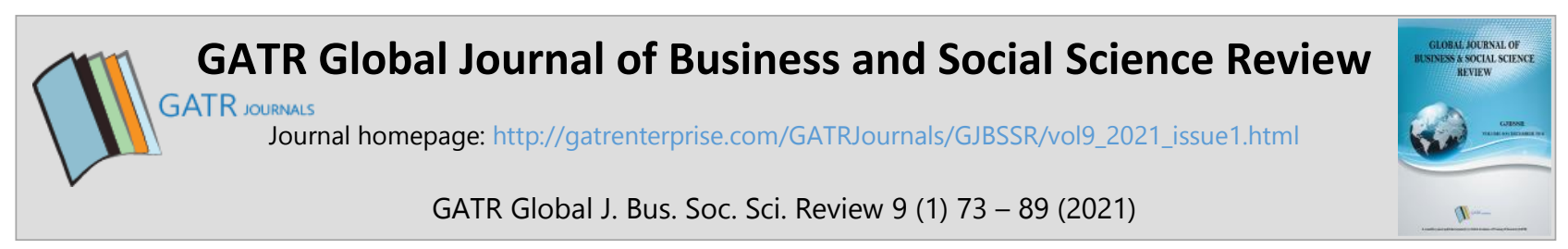

\title{
Forecasting the Logistics Demand of Guangxi Beibu Gulf Port
}

\author{
Guoyou Yue ${ }^{*}$ \\ ${ }^{1}$ Guangxi Key Laboratory of Cross-border E-commerce Intelligent Information Processing, Guangxi University of \\ Finance and Economics, 189 Daxuexi Road, Xixiangtang District, 530003, Nanning, China
}

\begin{abstract}
Objective - The objective of this paper is to establish the forecasting models of port cargo throughput and container throughput in Guangxi Beibu Gulf Port in the next 5 years, and to put forward the countermeasures of port logistics development in Guangxi Beibu Gulf Port according to the forecast results.

Methodology/Technique - The data of cargo throughput and container throughput of Guangxi Beibu Gulf Port and 3 port areas of Beihai, Fangcheng and Qinzhou in 2009-2020 are collected through the data of Guangxi Statistical Yearbook and Guangxi Statistical Bulletin. Based on 2019 and 2020, the forecasting models of cargo throughput and container throughput in Guangxi Beibu Gulf Port and 3 port areas of Beihai, Fangcheng and Qinzhou are establishe using a weighted moving average forecasting method. The cargo throughput and container throughput of Guangxi Beibu Gulf Port and 3 port areas of Beihai, Fangcheng and Qinzhou in 2020/2021-2025 are predicted.

Findings - The forecast results show that by 2025, the cargo throughput of Guangxi Beibu Gulf Port is expected to exceed 400 million tons, and the container throughput is expected to exceed 10 million TEU. According to the fitting diagram of forecast results and actual data, it can be seen that the accuracy of the forecast results is very high.

Novelty - It is innovative to select 2 base years in 2019 and 2020 to establish forecasting model. Based on the comparative analysis of the forecast results, this paper puts forward various measures to promote the development of port logistics of Guangxi Beibu Gulf port, such as strengthening the construction of port self-condition, strengthening the co-ordinated development of port and economic hinterland, speeding up the construction of port collection and distribution system, training and introducing all kinds of high-quality port logistics talents.
\end{abstract}

Type of Paper: Empirical.

JEL Classification: C53, R41.

Keywords: Logistics Demand Forecast; Cargo Throughput Forecast; Container Throughput Forecast; Weighted Moving Average Forecasting Method; Guangxi Beibu Gulf Port

Reference to this paper should be made as follows: Yue, N. (2021). Forecasting the Logistics Demand of Guangxi Beibu Gulf Port, GATR Global J. Bus. Soc. Sci. Review, 9(1): 73 - 89. https://doi.org/10.35609/gjbssr.2021.9.1(9)

\section{Introduction}

In February 2007, Guangxi Zhuang Autonomous Region People's Government integrated Fang Chenggang, Qinzhou, and Beihai established Guangxi Beibu Gulf International Port Group Co., LTD.

\footnotetext{
* Paper Info: Revised: December 25, 2020

Accepted: March 31, 2021

* Corresponding author: Guoyou Yue

E-mail: 563601374@qq.com

Affiliation: Guangxi Key Laboratory of Cross-border E-commerce Intelligent Information Processing, Guangxi University of Finance and Economics, China.
} 
At this point, Guangxi Beibu Gulf Port integration of 3 Guangxi Beibu Gulf Port ushered in a major development opportunity. Guangxi Beibu Gulf Port is one of the important ports in China's coastal cities open to the outside world. It is the meeting point of the 3 economic circles of South China, Southwest China, and ASEAN, and is also the most convenient land and sea passage between China and ASEAN countries. With the vigorous implementation of the "Belt and Road" initiative and the construction of the Western Land-Sea New Passage in China, Guangxi Beibu Gulf Port has become an important gateway and connection point for the implementation of these strategies. Its' strategic status keeps rising, and Guangxi Beibu Gulf Port has also developed rapidly.

Due to the rapid development of Guangxi Beibu Gulf Port in recent years, the development of Guangxi Beibu Gulf Port is expected from all walks of life. However, it is difficult to find the articles in the existing research literature to forecast the cargo throughput and container throughput of Guangxi Beibu Gulf Port, which makes the Guangxi Beibu Gulf Port Group lack the support of specific throughput data when formulating various development strategies. Therefore, the forecast research on cargo throughput and container throughput of Guangxi Beibu Gulf Port is carried out, and its changing law and trends are identified, which can better put forward timely and effective measures to develop and build Guangxi Beibu Gulf Port. As one of the important infrastructures to promote the economic and social development of Guangxi Beibu Gulf Economic Zone, Guangxi Beibu Gulf Port has a great impact on the opening and development of Guangxi Beibu Gulf Economic Zone and the improvement of the opening level of Guangxi port. Therefore, it is of great significance to promote the economic and social development of Guangxi to carry out the research on the port logistics demand forecast of Guangxi Beibu Gulf Port.

The rest of the paper is organized as follows. Section 2 gives a detailed literature review which mainly includes the port logistics demand forecasting method and the Guangxi Beibu Gulf port logistics development strategy related literature. Section 3 describes the methodology. The calculation idea and steps of weighted moving average forecasting method are introduced in detail. Section 4 describes the empirical analysis results and discussion in detail. The model of cargo throughput and container throughput of Guangxi Beibu Gulf Port is established, and the calculation results of the 2 models are compared and discussed. Section 5 summarizes the conclusions and gives several suggestions to improve the development of Guangxi Beibu Gulf Port.

\section{Literature review}

The forecast of port logistics demand in Guangxi Beibu Gulf port is mainly reviewed from 2 aspects: port cargo throughput forecasting method and port logistics development strategy of Guangxi Beibu Gulf port. A large number of scholars have put forward many effective forecasting methods in port cargo throughput forecasting methods. Some scholars use a single forecasting method to predict the port cargo throughput. According to the cargo throughput data of Qinzhou Port from 1999 to 2011, Hui Wang and Hao Chen (2013) cargo throughput of Qinzhou Port in 2015 and 2020 used the three-time exponential smoothing method. Long Ji (2009), Mingying Liu, Shizhou Weng, and Fengqing Huang (2018) predicted the port cargo throughput of Ningde Port and Fangcheng Port in the next few years respectively by using GM(1,1), a grey forecasting model, based on the characteristics of $\operatorname{GM}(1,1)$ applied to small sample data; the port cargo throughput had obvious volatility. Tingting Chen, Yiyi Chen (2009) and Ling Luan (2015) selected the main factors affecting port cargo throughput, such as GDP, foreign trade volume, and cargo volume, and used BP neural network model to predict port cargo throughput.

More and more scholars use more than 2 combined forecasting methods to predict port cargo throughput. Yunkang Zhang and Xiaoyu Zhang (2008) and Hanchao Wei, and Ruhe Xie (2012) used the exponential smoothing method and gray forecasting model $\operatorname{GM}(1,1)$ to establish a combined forecasting model to predict port logistics throughput. Shufu Ding and Bo Li (2004), Pingyi Fan, and Hongsheng Cao (2017) used the exponential smoothing method and regression analysis method to establish a combined forecasting model to carry out port logistics throughput prediction. Keman Hu et. al. (2018) optimized the model by combining the

GATR Global J. Bus. Soc. Sci. Review 9 (1) 73 - 89 (2021) 
grey model theory with the artificial neural network system and established the prediction algorithm of port cargo throughput based on the grey neural network. Sifan Yang et. al. (2020) used multiple linear regression analysis to select factors with a high degree of correlation and high degree of influence as the input of port cargo throughput and proposed BP neural network port cargo throughput forecasting model based on multifactor selection and error correction.

A large number of scholars in Guangxi Beibu Gulf port logistics development strategy put forward a representative point of view. Richard Gary and Khalid Bichou (2004) point out that port logistics is the main link of the supply chain, and the comprehensive method of establishing a port system can substantially reduce the cost and make customers satisfied. Wenhao Pan (2015), from the perspective of Guangxi Beibu Gulf Port Group, proposed measures to promote the development of Guangxi Beibu Gulf Port logistics, such as strengthening port railway transport, improving logistics service capacity, and coordinating the supply and demand matching of port logistics enterprises. Tao He (2018) proposed to accelerate the port construction in the Beibu Gulf region actively, undertaking the goods in and out of the southwest region, and strengthening the support for pillar industries in the port area to promote the high-speed coordinated development of "portcity" in the Beibu Gulf of Guangxi. Jingmin Wang (2011), Zhen Guo, and Yuyan Huang (2016) suggested that Guangxi Beibu Gulf Port logistics should develop in co-ordination with the hinterland economy. Jingmin Wang (2013) points out that Guangxi Beibu Gulf Port is the frontier and gateway of China-ASEAN maritime connectivity and proposed to build Guangxi Beibu Gulf Port into a regional international shipping center. Delong Wang (2015) proposed 4 measures to improve the construction of the modern logistics system of Guangxi Beibu Gulf Port, namely, the international channel system of the Maritime Silk Road, the commercial and financial system, the industrial cooperation system, and the modern logistics system.

The characteristics and forecast effects of the above methods on port cargo throughput forecast are different. Among them, time series based exponential smoothing and other forecasting methods require a single amount of data, generally based on the pre-period $\mathrm{N}$ period data required for the forecast data. By establishing the forecasting model to find the change law and trend of the data itself, the numerical value of the next few years is predicted. Such methods are easy to master, the required data is also readily available and the forecast results are more accurate when used to predict short and medium term data. There are also have many forecasting methods based on influencing factors, such as multiple regression, grey forecasting GM $(1,1)$, BP neural networks and so on. When using these methods, there are many factors that need to be considered to affect the port cargo throughput, the degree of influence between factors and target values is also different, data collection is difficult, the forecasting model is relatively complex, and it is only suitable for medium and long term data prediction. Guangxi Beibu Gulf Port as the "Belt and Road" important portal port and the western land and sea new channel construction hub port, its economic hinterland faces more than 10 provinces in western China, the range of factors and data are difficult to define, and early data collection is difficult. Combined with the availability and overall increasing trend of cargo throughput and container throughput data in Guangxi Beibu Gulf Port and 3 port areas of Beihai, Fangcheng and Qinzhou, this paper selects the weighted moving average forecasting method based on time series to establish a forecasting model to predict the cargo throughput and container throughput of Guangxi Beibu Gulf Port and 3 port areas of Beihai, Fangcheng and Qinzhou in 2021-2025. According to the analysis of the forecast results, the effective countermeasures for developing port logistics in Guangxi Beibu Gulf port are put forward.

\section{Methodology}

The concept model of weighted moving average forecasting method and its forecasting model are introduced below.

\subsection{Concept model of weighted moving average forecasting method}

The conceptual model of the weighted moving average forecasting method is established as follows. 
Firstly, the observation value of a certain period length is taken each time, and the value of the optimal step size $\mathrm{N}$ is determined by the average absolute error method. Secondly, the weighted moving average is calculated. In order to reflect the idea that the closer the observation value is to the next phase of the data, different weights are assigned to each phase of the optimal step size $\mathrm{N}$ period according to the time order from the next phase of the data. The closer the next period of data, the greater the weight of the observation value distribution, the smaller the weight of the observation value distribution farther from the next period of data. According to this method, the weighted average of the observation value in this period is calculated. Step by step in time order, for each additional period, remove the value of the previous period, and then calculate the new weighted average. All weighted averages obtained by this method are called first weighted moving averages. The second weighted moving averages are calculated by calculating the first weighted moving averages as the observation values.

Finally, the linear forecasting model of the second weighted moving average forecasting method is established. According to the first and second weighted moving averages calculated in the second step, the initial value and variable parameter of the linear forecasting model are calculated, and the predicted values for the next few years can be calculated by putting them into the linear forecasting model. This method is simple and easy to understand, and the required pre-observation data is simple and easy to obtain. It can eliminate or reduce the impact of random changes in the observation value, and find the evolution trend of the observation value. Moreover, the weighted method reflects the reality that the recent observation value has a greater impact on the predicted value, so as to ensure the forecast results are more accurate.

\subsection{Calculation method of the weighted moving average prediction method}

According to the concept model of weighted moving average forecasting method, the linear forecasting model of weighted moving average forecasting method is established by 3 calculation steps.

\subsubsection{Determination of the optimal step size $N$}

In order to better determine the optimal step size $\mathrm{N}$ of the weighted moving average forecasting method, the value of several step size $\mathrm{N}$ is generally selected according to the total period interval of the statistical data over the years, and then the average absolute error of each step size $\mathrm{N}$ is solved. The value with the minimum average absolute error is the value of the optimal step size $\mathrm{N}$. The mean absolute error is the average of the absolute values of all deviations of a single observation from the arithmetic mean. Compared with the average error, the average absolute error will not be offset by positive and negative because the deviation is changed into absolute value, so the average absolute error can better reflect the actual situation of the predicted value error. The calculation formula of the mean absolute error method is as follows:

$$
\frac{1}{n}=\sum_{n=1}^{n}\left|x_{i}-m(X)\right|
$$

In formula (1), $\mathrm{n}$ represents the number of data sets, $\mathrm{Xi}$ represents the value of individual data sets, and $\mathrm{m}(\mathrm{X})$ represents the arithmetic mean calculated under each given step size $\mathrm{n}$.

\subsubsection{Calculation of weighted moving average}

First of all, the first weighted moving average method was adopted for calculation. According to the value of the optimal step size $\mathrm{N}$ determined in the previous step, in order to better reflect the idea that the closer the observed value is, the greater the impact will be on the prediction results, the weight values of $\mathrm{N}, \mathrm{N}-1$, and...1, the size of $\mathrm{N}$ will affect the uniformity effect of the calculated results. The calculation formula of the first weighted moving average is as follows: 


$$
M_{t}^{(1)}=\frac{N x_{t-0}+(N-1) x_{t-1}+\ldots+x_{t-(N-1)}}{N+(N-1)+\ldots+1}
$$

In formula (2), $\mathrm{Mt}^{(1)}$ represents the first weighted moving average of the observed values in phase $\mathrm{t}$, and $\mathrm{xt}$ represents the data of the $t$ observation value, $t \geq N$.

Then, the second weighted moving average model is used for calculation. The calculation formula of the second weighted moving average is as follows:

$$
M_{t}^{(2)}=\frac{N M_{t-0}^{(1)}+(N-1) M_{t-1}^{(1)}+\ldots+M_{t-(N-1)}^{(1)}}{N+(N-1)+\ldots+1}
$$

In formula (3), $\mathrm{Mt}^{(2)}$ represents the second weighted moving average of the first weighted moving average in phase $t, t \geq N$.

\subsubsection{Linear forecasting model of the second weighted moving average forecasting method}

The linear prediction model of the second weighted moving average method is as follows:

$$
Y_{t+T}=a_{t}+b_{t} T
$$

In formula (4): $t$ represents the current time serial number; $T$ represents the number of time intervals from the current time to the predicted time, i.e. the lead time interval; at represents the intercept of the linear model; bt represents the slope of the linear model; $\mathrm{Yt}+\mathrm{T}$ represents the prediction for time $\mathrm{t}+\mathrm{T}$. Where the calculation formula of at and bt is:

$$
\begin{aligned}
& a_{t}=2 M_{t}^{(1)}-M_{t}^{(2)} \\
& b_{t}=\frac{2\left(M_{t}^{(1)}-M_{t}^{(2)}\right)}{N-1}
\end{aligned}
$$

After at and $b_{t}$ are calculated, the required prediction results can be calculated by substituting the above parameters into formula (4) to predict the value of a certain future year.

\section{Results and discussion}

The following will use the weighted moving average forecasting method to forecast the cargo throughput and container throughput of Guangxi Beibu Gulf Port and three port areas of Beihai, Fangcheng and Qinzhou.

\subsection{Forecast of cargo throughput of Guangxi Beibu Gulf Port}

\subsubsection{Cargo throughput and growth rate of Guangxi Beibu Gulf Port}

According to the Statistical Yearbook of Guangxi and statistical bulletin of each city, the cargo throughput and growth rate of Guangxi Beibu Gulf Port and three port areas of Beihai, Fangcheng and Qinzhou from 2009 to 2020 are collected as shown in Table 1. Table 1 shows the following phenomena described below. 
First, the cargo throughput of Guangxi Beibu Gulf Port maintained a relatively fast growth from 2009 to 2020, and the growth rate of cargo throughput maintained the top in China. In particular, after the integration of the 3 port areas of Guangxi Beibu Gulf Port, the growth rate in 2010-2011 was very fast, but it grew slowly in 2015-2016 and even showed negative growth in 2016.

Second, Qinzhou port area is the fastest-growing port area among the three port areas in terms of each port area, thanks to Guangxi Beibu Gulf Port's establishment of the Qinzhou port area as the home port for international container routes. Beihai port area maintained steady growth during these 11 years, which was also benefited from the construction of Tieshan Port and Tieshan Port Industrial Park in the Beihai port area. In recent years, the cargo throughput of Fangchenggang port area has shown a downward trend, but in 2020, the rapid recovery of growth, the urgent need to increase port industry to promote development.

Table 1. Cargo throughput and growth rate of Guangxi Beibu Gulf Port and three port areas from 2009 to 2020

(Unit: 10,000 tons)

\begin{tabular}{ccccccccc}
\hline & \multicolumn{2}{c}{ Beihai port area } & \multicolumn{2}{c}{$\begin{array}{c}\text { Fangcheng port } \\
\text { area }\end{array}$} & \multicolumn{2}{c}{ Qinzhou port area } & \multicolumn{2}{c}{$\begin{array}{c}\text { Guangi Beibu Gulf } \\
\text { Port }\end{array}$} \\
\cline { 2 - 9 } & $\begin{array}{c}\text { Through- } \\
\text { put }\end{array}$ & $\begin{array}{c}\text { Growth } \\
\text { rate }\end{array}$ & $\begin{array}{c}\text { Through } \\
\text {-put }\end{array}$ & $\begin{array}{c}\text { Growth } \\
\text { rate }\end{array}$ & $\begin{array}{c}\text { Throughp } \\
\text { ut }\end{array}$ & $\begin{array}{c}\text { Growth } \\
\text { rate }\end{array}$ & $\begin{array}{c}\text { Through } \\
\text { put }\end{array}$ & $\begin{array}{c}\text { Growth } \\
\text { rate }\end{array}$ \\
\hline 2009 & 1015 & - & 6379 & - & 2014 & - & 9408 & - \\
2010 & 1251 & $23.25 \%$ & 7650 & $19.92 \%$ & 3022 & $50.05 \%$ & 11923 & $26.73 \%$ \\
2011 & 1591 & $27.18 \%$ & 9024 & $17.96 \%$ & 4716 & $56.06 \%$ & 15331 & $28.58 \%$ \\
2012 & 1757 & $10.43 \%$ & 10058 & $11.46 \%$ & 5622 & $19.21 \%$ & 17437 & $13.74 \%$ \\
2013 & 2078 & $18.27 \%$ & 10560 & $4.99 \%$ & 6035 & $7.35 \%$ & 18673 & $7.09 \%$ \\
2014 & 2276 & $9.53 \%$ & 11501 & $8.91 \%$ & 6412 & $6.25 \%$ & 20189 & $8.12 \%$ \\
2015 & 2468 & $8.44 \%$ & 11504 & $0.03 \%$ & 6510 & $1.53 \%$ & 20482 & $1.45 \%$ \\
2016 & 2750 & $11.43 \%$ & 10688 & $-7.09 \%$ & 6954 & $6.82 \%$ & 20392 & $-0.44 \%$ \\
2017 & 3169 & $15.24 \%$ & 10355 & $-3.12 \%$ & 8338 & $19.90 \%$ & 21862 & $7.21 \%$ \\
2018 & 3387 & $6.88 \%$ & 10448 & $0.90 \%$ & 10151 & $21.74 \%$ & 23986 & $9.72 \%$ \\
2019 & 3496 & $3.22 \%$ & 10141 & $-2.94 \%$ & 11931 & $17.54 \%$ & 25568 & $6.60 \%$ \\
2020 & 3736 & $6.86 \%$ & 12182 & $20.13 \%$ & 13649 & $14.40 \%$ & 29567 & $15.64 \%$ \\
\hline
\end{tabular}

Data source: The data are collated from the statistical Yearbook of Guangxi from 2010 to 2020 and the monthly progress data of Guangxi in 2020.

\subsubsection{Determination the optimal step size of cargo throughput forecast of Guangxi Beibu Gulf Port}

The weighted moving average method should be used to forecast the cargo throughput of Guangxi Beibu Gulf Port and 3 port areas of Beihai, Fangcheng, Qinzhou. In order to improve the accuracy of the forecasting, the optimal calculation period, namely the value of step size $\mathrm{N}$, should be determined first. The cargo throughput data of Guangxi Beibu Gulf Port and 3 port areas from 2009 to 2020 in Table 1 are selected as follows: and the value of the optimal calculation step size $\mathrm{N}$ of Guangxi Beibu Gulf Port and three port areas using the weighted moving average method is determined by solving the average absolute error method. According to the actual situation of 12 phases of data in Guangxi Beibu Gulf Port and three port areas, $\mathrm{N}=2,3,5$, and 7 are planned to be calculated, and the number with the lowest average absolute error is the optimal value. Taking Guangxi Beibu Gulf Port as an example, the calculation results obtained according to formula (1) are shown in Table 2.

According to the calculation results in Table 2, when $\mathrm{N}=2$, the average absolute error value calculated by the cargo throughput of Guangxi Beibu Gulf Port is the smallest. Therefore, when the weighted moving average forecasting method is adopted to forecast the cargo throughput of Guangxi Beibu Gulf Port in the coming years, it is the most reasonable to take $\mathrm{N}=2$ for calculation. 
By the same method, we calculate the mean absolute error of Beihai, Fangcheng, Qinzhou 3 port areas at different values of step size. The results show that when $\mathrm{N}=2$, Beihai, Fangcheng and Qinzhou, 3 port areas mean absolute error value is the smallest. So the weighted moving average forecasting method is adopted to forecast the cargo throughput of Beihai, Fangcheng and Qinzhou three port areas in future years when $\mathrm{N}=2$ to calculate the most reasonable.

Table 2. calculation results of the optimal step size of cargo throughput of Guangxi Beibu Gulf Port from 2009 to 2020

(Unit: 10,000 tons)

\begin{tabular}{|c|c|c|c|c|c|c|c|c|c|}
\hline \multirow[b]{2}{*}{ Year } & \multirow{2}{*}{$\begin{array}{c}\text { Cargo } \\
\text { throughput } \\
\text { of Guangxi } \\
\text { Beibu Gulf } \\
\text { Port }\end{array}$} & \multicolumn{2}{|c|}{$\mathrm{N}=2$} & \multicolumn{2}{|c|}{$\mathrm{N}=3$} & \multicolumn{2}{|c|}{$\mathrm{N}=5$} & \multicolumn{2}{|c|}{$\mathrm{N}=7$} \\
\hline & & $\begin{array}{c}\text { Predictiv } \\
\text { e value }\end{array}$ & $\begin{array}{l}\text { Absolut } \\
\text { e error }\end{array}$ & $\begin{array}{c}\text { Predictiv } \\
\text { e value }\end{array}$ & $\begin{array}{l}\text { Absolut } \\
\text { e error }\end{array}$ & $\begin{array}{c}\text { Predictiv } \\
\text { e value }\end{array}$ & $\begin{array}{l}\text { Absolut } \\
\text { e error }\end{array}$ & $\begin{array}{l}\text { Predictiv } \\
\text { e value }\end{array}$ & $\begin{array}{l}\text { Absolut } \\
\text { e error }\end{array}$ \\
\hline 2009 & 9408 & & & & & & & & \\
\hline 2010 & 11923 & 10665.50 & 1257.50 & & & & & & \\
\hline 2011 & 15331 & 13627.00 & 1704.00 & 12220.67 & 3110.33 & & & & \\
\hline 2012 & 17437 & 16384.00 & 1053.00 & 14897.00 & 2540.00 & & & & \\
\hline 2013 & 18673 & 18055.00 & 618.00 & 17147.00 & 1526.00 & 14554.40 & 4118.60 & & \\
\hline 2014 & 20189 & 19431.00 & 758.00 & 18766.33 & 1422.67 & 16710.60 & 3478.40 & & \\
\hline 2015 & 20482 & 20335.50 & 146.50 & 19781.33 & 700.67 & 18422.40 & 2059.60 & 16206.14 & 4275.86 \\
\hline 2016 & 20392 & 20437.00 & 45.00 & 20354.33 & 37.67 & 19434.60 & 957.40 & 17775.29 & 2616.71 \\
\hline 2017 & 21862 & 21127.00 & 735.00 & 20912.00 & 950.00 & 20319.60 & 1542.40 & 19195.14 & 2666.86 \\
\hline 2018 & 23986 & 22924.00 & 1062.00 & 22080.00 & 1906.00 & 21382.20 & 2603.80 & 20431.57 & 3554.43 \\
\hline 2019 & 25568 & 24777.00 & 791.00 & 23805.33 & 1762.67 & 22458.00 & 3110.00 & 21593.14 & 3974.86 \\
\hline 2020 & 29567 & 27567.50 & 1999.50 & 26373.67 & 3193.33 & 24275.00 & 5292.00 & 23149.43 & 6417.57 \\
\hline \multicolumn{2}{|c|}{$\begin{array}{c}\text { Mean absolute } \\
\text { error }\end{array}$} & & 924.50 & & 1714.93 & & 2895.28 & & 3917.71 \\
\hline
\end{tabular}

\subsubsection{Forecast the cargo throughput of Guangxi Beibu Gulf Port}

The cargo throughput data of Guangxi Beibu Gulf Port from 2009 to 2020 in Table 1 are selected as follows. The step size $\mathrm{N}=2$ is taken and substituted into formula (2), formula (3), formula (5) and formula (6) to obtain the parameter values of the cargo throughput forecasting model of Guangxi Beibu Gulf Port, as shown in Table 3.

Table 3. Parameter values of the forecast model of Guangxi Beibu Gulf Port's cargo throughput

\begin{tabular}{cccccc}
\hline Year & $\begin{array}{c}\text { Cargo } \\
\text { throughput of } \\
\text { Guangxi Beibu } \\
\text { Gulf Port }\end{array}$ & $M_{t}^{(1)}$ & $M_{t}^{(2)}$ & $a_{t}$ & $b_{t}$ \\
\hline 2009 & 9408 & & & & \\
2010 & 11923 & 10665.50 & & & \\
2011 & 15331 & 13627.00 & 12146.25 & 15107.75 & 2961.50 \\
2012 & 17437 & 16384.00 & 15005.50 & 17762.50 & 2757.00 \\
2013 & 18673 & 18055.00 & 17219.50 & 18890.50 & 1671.00 \\
2014 & 20189 & 19431.00 & 18743.00 & 20119.00 & 1376.00 \\
2015 & 20482 & 20335.50 & 19883.25 & 20787.75 & 904.50
\end{tabular}




\begin{tabular}{lccccc}
2016 & 20392 & 20437.00 & 20386.25 & 20487.75 & 101.50 \\
2017 & 21862 & 21127.00 & 20782.00 & 21472.00 & 690.00 \\
2018 & 23986 & 22924.00 & 22025.50 & 23822.50 & 1797.00 \\
2019 & 25568 & 24777.00 & 23850.50 & 25703.50 & 1853.00 \\
2020 & 29567 & 27567.50 & 26172.25 & 28962.75 & 2790.50 \\
\hline
\end{tabular}

In order to better contrast effect, 2019 and 2020 are selected as base years to establish the weighted moving average forecasting model of Guangxi Beibu Gulf Port's cargo throughput, respectively. The specific model is as follows:

Base year forecasting model for Guangxi Beibu Gulf Port in 2019: $\mathrm{Y}^{\mathrm{H}} 2019+\mathrm{T}=25703.50+1853.00 \mathrm{~T}$

Base year forecasting model for Guangxi Beibu Gulf Port in 2020: $\mathrm{Y}^{\mathrm{H}}{ }_{2020+\mathrm{T}}=28962.75+2790.50 \mathrm{~T}$

By using the same method, the weighted moving average forecasting model of cargo throughput of Beihai, Fangcheng and Qinzhou 3 port areas are calculated as follows:

Base year forecasting model of Beihai port area in 2019: $Y^{B H}{ }_{2019+T}=3523.25+163.50 \mathrm{~T}$

Base year forecasting model of Beihai port area in 2020: $Y^{B H}{ }_{2020+T}=3703.25+174.50 \mathrm{~T}$

Base year forecasting model of Fangcheng port area in 2019: $Y^{F H}{ }_{2019+T}=10241.00-107.00 \mathrm{~T}$

Base year forecasting model of Fangcheng port area in 2020: $Y^{F H}{ }_{2020+T}=11595.00+867.00 \mathrm{~T}$

Base year forecasting model of Qinzhou port area in 2019: $Y^{\mathrm{QH}}{ }_{2019+T}=11939.25+1796.50 \mathrm{~T}$

Base year forecasting model of Qinzhou port area in 2020: $Y^{\mathrm{QH}}{ }_{2020+T}=13664.50+1749.00 \mathrm{~T}$

According to the above forecasting model, the forecast cargo throughput of Guangxi Beibu Gulf Port and three port areas of Beihai, Fangcheng and Qinzhou in 2020/2021-2025 can be calculated, as shown in Table 4.

Table 4. Forecast results of cargo throughput of Guangxi Beibu Gulf Port and three port areas in 2020/2021-2025

(Unit: 10,000 tons)

\begin{tabular}{ccccccccc}
\hline & \multicolumn{2}{c}{ Beihai port area } & \multicolumn{3}{c}{ Fangcheng port area } & \multicolumn{2}{c}{ Qinzhou port area } & \multicolumn{2}{c}{$\begin{array}{c}\text { Guangxi Beibu Gulf } \\
\text { Port }\end{array}$} \\
\cline { 2 - 9 } Yeary & Base year & Base year & Base year & Base year & Base year & Base year & Base year & Base year \\
& 2019 & 2020 & 2019 & 2020 & 2019 & 2020 & 2019 & 2020 \\
\hline 2020 & 3686.75 & - & 10134.00 & - & 13735.75 & - & 27556.50 & - \\
2021 & 3850.25 & 3877.75 & 10027.00 & 12462.00 & 15532.25 & 15413.50 & 29409.50 & 31753.25 \\
2022 & 4013.75 & 4052.25 & 9920.00 & 13329.00 & 17328.75 & 17162.50 & 31262.50 & 34543.75 \\
2023 & 4177.25 & 4226.75 & 9813.00 & 14196.00 & 19125.25 & 18911.50 & 33115.50 & 37334.25 \\
2024 & 4340.75 & 4401.25 & 9706.00 & 15063.00 & 20921.75 & 20660.50 & 34968.50 & 40124.75 \\
2025 & 4504.25 & 4575.75 & 9599.00 & 15930.00 & 22718.25 & 22409.50 & 36821.50 & 42915.25 \\
\hline
\end{tabular}

\subsection{Container throughput forecast of Guangxi Beibu Gulf Port}

\subsubsection{Container throughput and growth rate of Guangxi Beibu Gulf Port}

According to the monthly statistical report of Guangxi Beibu Gulf Economic Zone, Guangxi Bluebook "Analysis and Forecast of Guangxi Economic Situation", statistical bulletin of all cities of Guangxi, etc., the 
container throughput and growth rate of Guangxi Beibu Gulf Port and 3 port areas from 2009 to 2020 are shown in Table 5. Table 5 shows the following phenomena described below.

First, the container throughput of Guangxi Beibu Gulf port maintained a relatively fast growth rate from 2009 to 2020. In 2020, the container throughput of Guangxi Beibu Gulf port was nearly 15 times that of 2009. From 2015 to 2020, the container throughput of Guangxi Beibu Gulf Port maintained a high speed and stable growth of more than $25 \%$ each year, especially the fastest growth rate in 2010 after integrating the 3 port areas of Guangxi Beibu Gulf Port.

Second, in terms of each port area, the Qinzhou port area is the fastest-growing port area among the 3 port areas. The container throughput of the Qinzhou port area in 2020 is nearly 40 times that of 2009. This is due to the fact that Guangxi Beibu Gulf Port has made Qinzhou port area as the home port of international container routes. The Beihai port area maintained steady growth in the past 12 years. In 2020, the container throughput of Beihai port area was more than 11 times that of 2009, thanks to the construction of Tieshan Port and Tieshan Port Industrial Park in Beihai port area. In the past 12 years, the Fangcheng port area's container throughput has experienced a very unstable growth, only increasing nearly 3 times. Moreover, it showed a sharp decline in 2016, which was most affected by international trade. Therefore, it is in urgent need of growth and development driven by the port-neighboring industry.

Table 5. Container throughput and growth rate of Guangxi Beibu Gulf Port and three port areas from 2009 to 2020

(Unit: 10,000 TEU)

\begin{tabular}{ccccccccc}
\hline \multirow{2}{*}{ Year } & \multicolumn{2}{c}{ Beihai port area } & \multicolumn{2}{c}{ Fangcheng port area } & \multicolumn{2}{c}{ Qinzhou port area } & \multicolumn{2}{c}{$\begin{array}{c}\text { Guangxi Beibu Gulf } \\
\text { Port }\end{array}$} \\
\cline { 2 - 9 } & $\begin{array}{c}\text { Through } \\
\text { put }\end{array}$ & $\begin{array}{c}\text { Growth } \\
\text { rate }\end{array}$ & $\begin{array}{c}\text { Throughp } \\
\text { ut }\end{array}$ & $\begin{array}{c}\text { Growth } \\
\text { rate }\end{array}$ & $\begin{array}{c}\text { Through } \\
\text { put }\end{array}$ & $\begin{array}{c}\text { Growth } \\
\text { rate }\end{array}$ & $\begin{array}{c}\text { Through } \\
\text { put }\end{array}$ & $\begin{array}{c}\text { Growth } \\
\text { rate }\end{array}$ \\
\hline 2009 & 4.42 & - & 20.36 & - & 10.09 & - & 34.87 & - \\
2010 & 6.18 & $39.82 \%$ & 25.10 & $23.28 \%$ & 25.09 & 148.66 & 56.37 & $61.66 \%$ \\
2011 & 7.10 & $14.89 \%$ & 26.60 & $5.98 \%$ & 40.02 & $59.51 \%$ & 73.72 & $30.78 \%$ \\
2012 & 8.02 & $12.96 \%$ & 27.02 & $1.58 \%$ & 47.40 & $18.44 \%$ & 82.44 & $11.83 \%$ \\
2013 & 8.40 & $4.74 \%$ & 29.22 & $8.14 \%$ & 60.10 & $26.79 \%$ & 97.72 & $18.53 \%$ \\
2014 & 9.60 & $14.29 \%$ & 32.20 & $10.20 \%$ & 70.20 & $16.81 \%$ & 112.00 & $14.61 \%$ \\
2015 & 10.70 & $11.46 \%$ & 36.10 & $12.11 \%$ & 94.17 & $34.15 \%$ & 141.52 & $25.87 \%$ \\
2016 & 15.37 & $43.64 \%$ & 26.71 & $-26.01 \%$ & 137.4 & $45.91 \%$ & 179.48 & $27.32 \%$ \\
2017 & 23.98 & $56.02 \%$ & 26.89 & $0.67 \%$ & 177.0 & $28.82 \%$ & 227.87 & $26.96 \%$ \\
2018 & 26.49 & $10.47 \%$ & 31.20 & $16.03 \%$ & 232.45 & $31.33 \%$ & 290.14 & $27.33 \%$ \\
2019 & 38.34 & $44.73 \%$ & 42.10 & $34.94 \%$ & 301.60 & $29.75 \%$ & 382.04 & $31.67 \%$ \\
2020 & 50.02 & $30.46 \%$ & 60.10 & $42.76 \%$ & 395.04 & $30.98 \%$ & 505.16 & $32.23 \%$ \\
\hline
\end{tabular}

Data source: (1) From 2015 to 2020, Guangxi Beibu Gulf Economic Zone monthly statistical report data collated. (2) Guangxi Blue Book, Analysis and Forecast of Guangxi Economic Situation, Guangxi People's Publishing House, 2010. (3) Statistical bulletins of cities and regions.

\subsubsection{Determination the optimal step size of container throughput forecast of Guangxi Beibu Gulf Port}

The weighted moving average method should be used to forecast the container throughput of Guangxi Beibu Gulf Port and 3 port areas of Beihai, Fangcheng and Qinzhou. In order to improve the accuracy of the forecasting, the optimal calculation period, namely the value of step size $\mathrm{N}$, should be determined first. The container throughput data of Guangxi Beibu Gulf Port and 3 port areas from 2009 to 2020 in Table 5 are selected as follows, and the value of the optimal calculation step size $\mathrm{N}$ of Guangxi Beibu Gulf Port and 3 port areas using the weighted moving average method is determined by solving the average absolute error 
method. According to the actual situation of 12 phases of data in Guangxi Beibu Gulf Port and three port areas, $\mathrm{N}=2,3,5$, and 7 are planned to be calculated, and the number with the lowest average absolute error is the optimal value. Taking Guangxi Beibu Gulf Port as an example, the calculation results obtained according to formula (1) are shown in Table 6.

According to the calculation results in Table 6 , when $\mathrm{N}=2$, the average absolute error value calculated by the container throughput of Guangxi Beibu Gulf Port is the smallest. Therefore, when the weighted moving average forecasting method is adopted to forecast the container throughput of Guangxi Beibu Gulf Port in the coming years, it is the most reasonable to take $\mathrm{N}=2$ for calculation.

By the same method to calculate the mean absolute error of three port areas of Beihai, Fangcheng and Qinzhou at different values of step size. The results show that when $\mathrm{N}=2$, Beihai, Fangcheng, Qinzhou port areas mean absolute error value is the smallest. So the weighted moving average forecasting method is adopted to forecast the container throughput of Beihai, Fangcheng, Qinzhou port areas in future years when $\mathrm{N}=2$ to calculate the most reasonable.

Table 6. Calculation results of the optimal step size of container throughput of Guangxi Beibu Gulf Port from 2009 to 2020

(Unit: 10,000 TEU)

\begin{tabular}{|c|c|c|c|c|c|c|c|c|c|}
\hline \multirow[b]{2}{*}{ Year } & \multirow{2}{*}{$\begin{array}{c}\text { Container } \\
\text { throughput } \\
\text { of Guangxi } \\
\text { Beibu Gulf } \\
\text { Port }\end{array}$} & \multicolumn{2}{|c|}{$\mathrm{N}=2$} & \multicolumn{2}{|c|}{$\mathrm{N}=3$} & \multicolumn{2}{|c|}{$\mathrm{N}=5$} & \multicolumn{2}{|c|}{$\mathrm{N}=7$} \\
\hline & & $\begin{array}{c}\text { Predictiv } \\
\text { e value }\end{array}$ & $\begin{array}{l}\text { Absolut } \\
\text { e error }\end{array}$ & $\begin{array}{c}\text { Predictiv } \\
\text { e value }\end{array}$ & $\begin{array}{l}\text { Absolut } \\
\text { e error }\end{array}$ & $\begin{array}{l}\text { Predictiv } \\
\text { e value }\end{array}$ & $\begin{array}{l}\text { Absolut } \\
\text { e error }\end{array}$ & $\begin{array}{c}\text { Predictiv } \\
\text { e value }\end{array}$ & $\begin{array}{l}\text { Absolute } \\
\text { error }\end{array}$ \\
\hline 2009 & 34.87 & & & & & & & & \\
\hline 2010 & 56.37 & 45.62 & 10.75 & & & & & & \\
\hline 2011 & 73.72 & 65.05 & 8.68 & 54.99 & 18.73 & & & & \\
\hline 2012 & 82.44 & 78.08 & 4.36 & 70.84 & 11.60 & & & & \\
\hline 2013 & 97.72 & 90.08 & 7.64 & 84.63 & 13.09 & 69.02 & 28.70 & & \\
\hline 2014 & 112 & 104.86 & 7.14 & 97.39 & 14.61 & 84.45 & 27.55 & & \\
\hline 2015 & 141.52 & 126.76 & 14.76 & 117.08 & 24.44 & 101.48 & 40.04 & 85.52 & 56.00 \\
\hline 2016 & 179.48 & 160.50 & 18.98 & 144.33 & 35.15 & 122.63 & 56.85 & 106.18 & 73.30 \\
\hline 2017 & 227.87 & 203.68 & 24.20 & 182.96 & 44.91 & 151.72 & 76.15 & 130.68 & 97.19 \\
\hline 2018 & 290.14 & 259.01 & 31.14 & 232.50 & 57.64 & 190.20 & 99.94 & 161.60 & 128.54 \\
\hline 2019 & 382.04 & 336.09 & 45.95 & 300.02 & 82.02 & 244.21 & 137.83 & 204.40 & 177.64 \\
\hline 2020 & 505.16 & 443.60 & 61.56 & 392.45 & 112.71 & 316.94 & 188.22 & 262.60 & 242.56 \\
\hline \multicolumn{2}{|c|}{$\begin{array}{c}\text { Mean absolute } \\
\text { error }\end{array}$} & & 21.38 & & 41.49 & & 81.91 & & 129.21 \\
\hline
\end{tabular}

\subsubsection{Forecast the container throughput of Guangxi Beibu Gulf Port}

The container throughput data of Guangxi Beibu Gulf Port from 2009 to 2020 in Table 5 are selected as follows. The step size $\mathrm{N}=2$ is taken and substituted into formula (2), formula (3), formula (5), and formula (6) to obtain the parameter values of the container throughput forecasting model of Guangxi Beibu Gulf Port, as shown in Table 7. 
Table 7. Parameter values of the forecast model of Guangxi Beibu Gulf Port's container throughput

\begin{tabular}{|c|c|c|c|c|c|}
\hline Year & $\begin{array}{c}\text { Container } \\
\text { throughput of } \\
\text { Guangxi Beibu } \\
\text { Gulf Port }\end{array}$ & $M_{t}^{(1)}$ & $M_{t}^{(2)}$ & $a_{t}$ & $b_{t}$ \\
\hline 2009 & 34.87 & & & & \\
\hline 2010 & 56.37 & 45.62 & & & \\
\hline 2011 & 73.72 & 65.05 & 55.33 & 74.76 & 19.43 \\
\hline 2012 & 82.44 & 78.08 & 71.56 & 84.60 & 13.04 \\
\hline 2013 & 97.72 & 90.08 & 84.08 & 96.08 & 12.00 \\
\hline 2014 & 112.00 & 104.86 & 97.47 & 112.25 & 14.78 \\
\hline 2015 & 141.52 & 126.76 & 115.81 & 137.71 & 21.90 \\
\hline 2016 & 179.48 & 160.50 & 143.63 & 177.37 & 33.74 \\
\hline 2017 & 227.87 & 203.68 & 182.09 & 225.26 & 43.18 \\
\hline 2018 & 290.14 & 259.01 & 231.34 & 286.67 & 55.33 \\
\hline 2019 & 382.04 & 336.09 & 297.55 & 374.63 & 77.09 \\
\hline 2020 & 505.16 & 443.60 & 389.85 & 497.36 & 107.51 \\
\hline
\end{tabular}

In order to better contrast effect, 2019 and 2020 are selected as base years to establish the weighted moving average forecasting model of Guangxi Beibu Gulf Port's container throughput, respectively. The specific model is as follows:

Base year forecasting model for Guangxi Beibu Gulf Port in 2019: $Y_{2019+1}^{J}=374.63+77.09 \mathrm{~T}$

Base year forecasting model for Guangxi Beibu Gulf Port in 2020: $Y_{2020+T}^{J}=497.36+107.51 \mathrm{~T}$

By using the same method, the weighted moving average forecasting model of container throughput of Beihai, Fangcheng, and Qinzhou three port areas are calculated as follows:

Base year forecasting model of Beihai port area in 2019: $Y^{B J}{ }_{2019+T}=497.36+107.51 \mathrm{~T}$

Base year forecasting model of Beihai port area in 2020: $Y^{B J}{ }_{2020+T}=50.06+11.77 \mathrm{~T}$

Base year forecasting model of Fangcheng port area in 2019: $Y^{F J}{ }_{2019+T}=40.45+7.61 \mathrm{~T}$

Base year forecasting model of Fangcheng port area in 2020: $Y^{F J}{ }_{2020+T}=58.33+14.45 \mathrm{~T}$

Base year forecasting model of Qinzhou port area in 2019: $Y^{Q J}{ }_{2019+T}=298.18+62.30 \mathrm{~T}$

Base year forecasting model of Qinzhou port area in 2020: $Y^{Q J}{ }_{2020+T}=388.97+81.30 \mathrm{~T}$

According to the above forecasting model, the forecast container throughput of Guangxi Beibu Gulf Port and 3 port areas of Beihai, Fangcheng and Qinzhou in 2020/2021-2025 can be calculated, as shown in Table 8.

Table 8. Forecast results of container throughput of Guangxi Beibu Gulf Port and three port areas in 2020/2021-2025

(Unit: 10,000 TEU)

\begin{tabular}{ccccccccc}
\hline \multirow{2}{*}{ Year } & \multicolumn{2}{c}{ Beihai port area } & \multicolumn{2}{c}{ Fangcheng port area } & \multicolumn{2}{c}{ Qinzhou port area } & \multicolumn{2}{c}{ Guangxi Beibu Gulf } \\
\cline { 2 - 8 } & Base year & Base year & Base year & Base year & Base year & Base year & Base year & Base year \\
& 2019 & 2020 & 2019 & 2020 & 2019 & 2020 & 2019 & 2020 \\
\hline 2020 & 43.19 & - & 48.06 & - & 360.48 & - & 451.72 & - \\
2021 & 50.37 & 61.83 & 55.66 & 72.78 & 422.78 & 470.26 & 528.80 & 604.87
\end{tabular}

GATR Global J. Bus. Soc. Sci. Review 9 (1) 73 - 89 (2021) 
Guoyou Yue

\begin{tabular}{ccccccccc}
2022 & 57.55 & 73.59 & 63.27 & 87.23 & 485.08 & 551.56 & 605.89 & 712.375 \\
2023 & 64.73 & 85.36 & 70.87 & 101.68 & 547.38 & 632.85 & 682.97 & 819.885 \\
2024 & 71.91 & 97.12 & 78.48 & 116.13 & 609.68 & 714.15 & 760.06 & 927.395 \\
2025 & 79.09 & 108.89 & 86.08 & 130.58 & 671.98 & 795.44 & 837.14 & 1034.905 \\
\hline
\end{tabular}

\subsection{Discussion}

\subsubsection{Discussion of the forecast results of cargo throughput of Guangxi Beibu Gulf Port}

In order to better show two different base year in calculation of the applicability of the forecast results, the choice of the actual cargo throughput of Guangxi Beibu Gulf Port and 3 port areas of Beihai, Fangcheng and Qinzhou in 2009-2019/2020 and the forecasting cargo throughput in 2020/2021-2025 will require continuous comparing of the two different base years to calculate of the changing trend of forecast results and analyses of the rationality. Figure 1 shows the fitting figure of the cargo throughput of Guangxi Beibu Gulf Port and 3 port areas of Beihai, Fangcheng and Qinzhou from 2009 to 2025.

According to the forecast results in Table 4 and Figure 1, the cargo throughput of Guangxi Beibu Gulf Port and the 3 port areas present the characteristics described below.

First, the cargo throughput of Guangxi Beibu Gulf Port is increasing year by year. Despite the impact of the trade war and the tightening of global foreign trade, Guangxi Beibu Gulf Port maintains a relatively rapid growth rate thanks to the construction of the Western Land-Sea New Passage and the vigorous development of Guangxi economy and society. The cargo throughput of Guangxi Beibu Gulf Port is expected to exceed 400 million tons by 2025 .

Second, the cargo throughput of three port areas of Beihai, Fangcheng and Qinzhou presented different development trends. The cargo throughput of the Beihai port area and Qinzhou port area will maintain a relatively fast growth rate, especially the Qinzhou port area that will benefit from the construction of the Western Land-Sea New Passage in China, the cargo throughput will grow the fastest. The cargo throughput of the Fangcheng port area is unstable, which may be caused by the trade war and the tightening of global foreign trade. It is urgent to adjust the strategy to change this unfavorable situation.

Third, the cargo throughput of Guangxi Beibu Gulf Port and 3 port areas show different characteristics when 2 base years are used. The forecast value of 2019 base year for the cargo throughput of Beihai port area and Qinzhou port area is highly consistent with the forecast value of 2020 base year, and the difference between the 2 base years is very small. The forecast value of the $\mathrm{t} 2$ base years keeps growing, and the growth rate of Qinzhou port area is faster. The forecast value of the cargo throughput of Fangcheng port area in the base year of 2019 shows a slow downward trend, while the forecast value of the base year of 2020 shows a fast upward trend. There is a big difference between the two forecast values of the base year, which is because the cargo throughput of Fangcheng port area in 2020 has reversed the original downward trend by a large increase. The cargo throughput of Guangxi Beibu Gulf Port maintains a rapid growth trend both in the base year of 2019 and 2020, and the growth rate is faster in the base year of 2020. 
Fitting figure of cargo throughput of Guangxi Beibu Gulf Port and three port areas from 2009 to 2025 based on 2 base year forecast results

(Units: 10,000 tons)

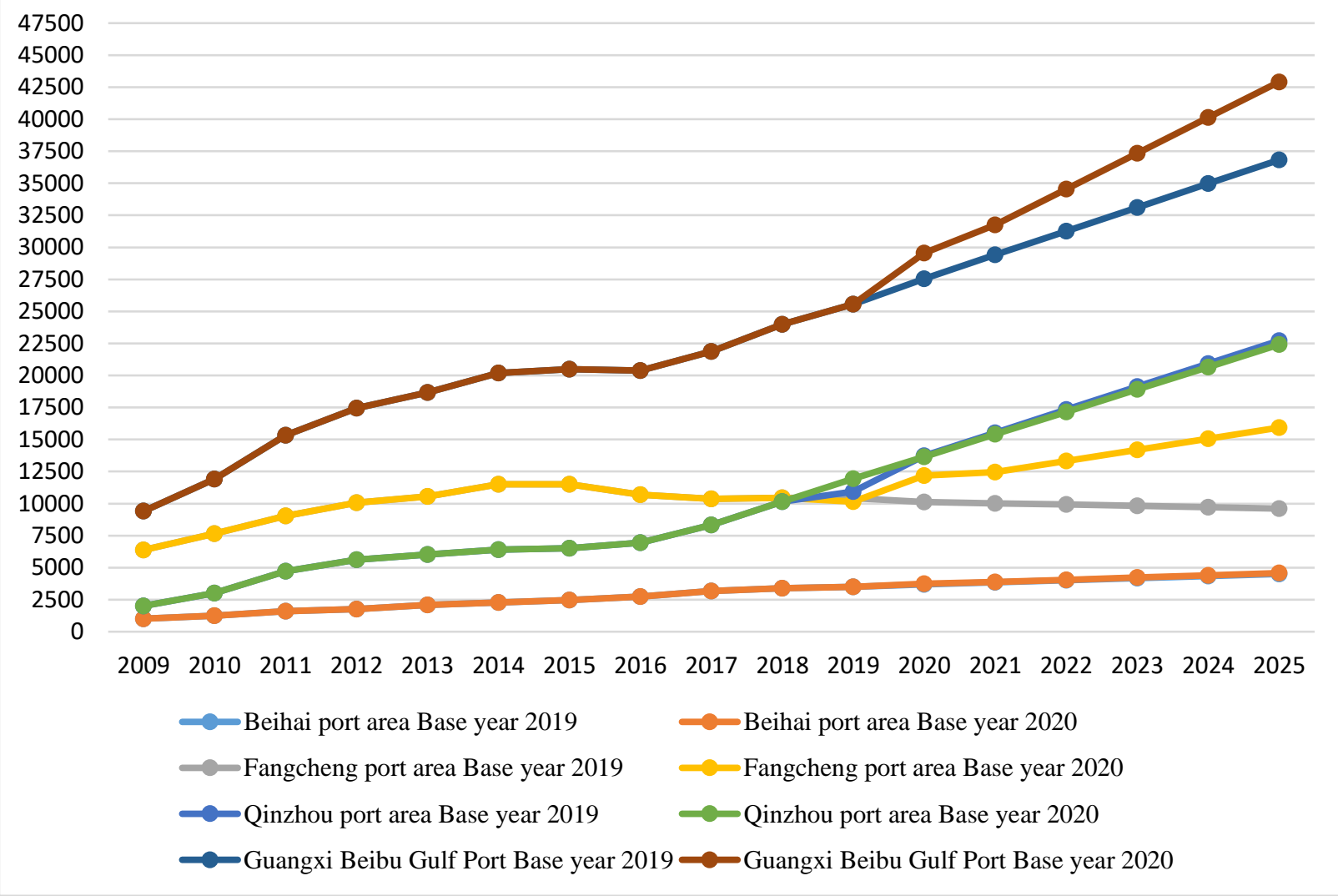

Figure 1. The fitting figure of cargo throughput of Guangxi Beibu Gulf Port and three port areas from 2009 to 2025 based on two base year forecast results

\subsubsection{Discussion of the forecast results of container throughput of Guangxi Beibu Gulf Port}

In order to better show 2 different base year to calculate the applicability of the forecast results, the choice of the actual container throughput of Guangxi Beibu Gulf Port and three port areas of Beihai, Fangcheng and Qinzhou in 2009-2019/2020 and the forecasting container throughput in 2020/2021-2025 was continuously drawn and compared. Two different base years in calculating the changing trend of forecast results have been analyzed its rationality. Figure 2 shows the fitting figure of the container throughput of Guangxi Beibu Gulf Port and three port areas of Beihai, Fangcheng and Qinzhou from 2009 to 2025. 


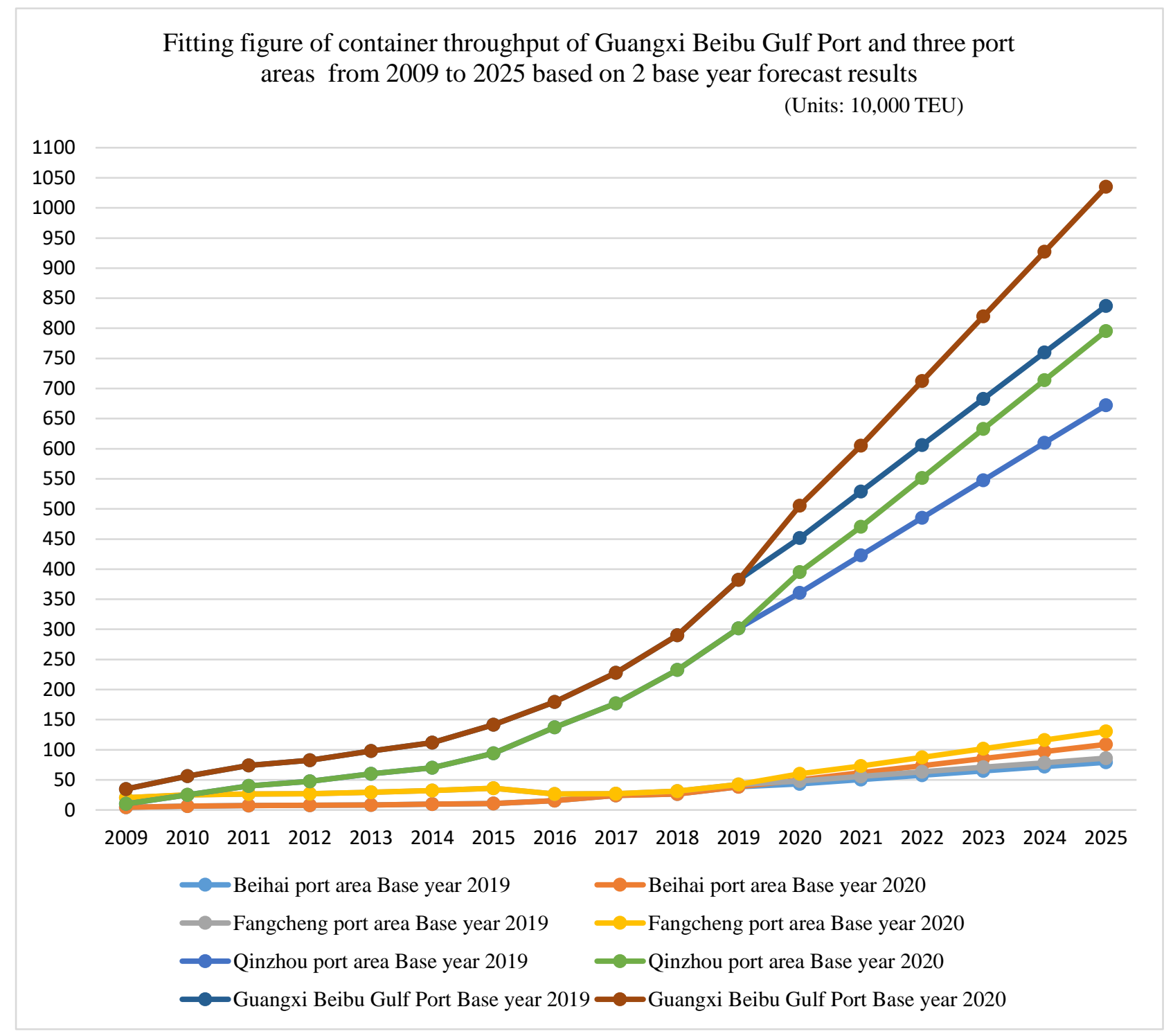

Figure 2. Fitting figure of container throughput of Guangxi Beibu Gulf Port and three port areas from 2009 to 2025 based on two base year forecast results

According to Table 8 and fitting Figure 2, the container throughput of Guangxi Beibu Gulf Port and the three port areas presents the characteristics described below.

First, the container throughput of Guangxi Beibu Gulf Port is increasing year by year. Despite the impact of the trade war and the tightening of global foreign trade, Guangxi Beibu Gulf Port has maintained a relatively fast growth rate, and the container throughput of Guangxi Beibu Gulf Port is expected to exceed 10 million TEU by 2025.

Second, the container throughput of 3 port areas of Beihai, Fangcheng and Qinzhou presented different development trends. Although the container throughput of Beihai port area and Fangcheng port area maintains a relatively fast growth rate, due to the small base, the forecast results calculated by the 2 base years show that the proportion of container throughput of Beihai port area and Fangcheng port area in Guangxi Beibu Gulf Port will gradually decline. The container throughput of the Qinzhou port area will maintain rapid growth, and expected to reach 8 million TEU by 2025. Qinzhou port area benefits from the construction of the Western Land-Sea New Passage in China and the construction of Guangxi Beibu Gulf Port as the main international container port. The Qinzhou port area container's growth trend determines the growth trend of Guangxi Beibu Gulf Port's container business. 
Third, the container throughput of Guangxi Beibu Gulf Port and three port areas calculated by using two base years shows similar characteristics. Guangxi Beibu Gulf Port and three port areas of Beihai, Fangcheng and Qinzhou forecast container throughput growth faster in the base year of 2020. Furthermore, in recent years, Guangxi Beibu Gulf Port benefits from the construction of the Western Land-Sea New Passage in China and the rapid economic and social development of Guangxi Beibu Gulf Economic Zone. The container throughput of Guangxi Beibu Gulf Port will maintain a steady and rapid development trend.

\section{Conclusion}

According to the above forecast results of cargo throughput and container throughput of Guangxi Beibu Gulf Port and three port areas of Beihai, Fangcheng and Qinzhou using weighted moving average forecasting method, the conclusions referred to below can be drawn. First, the cargo throughput and container throughput of Guangxi Beibu Gulf Port will maintain rapid growth from 2021 to 2025. By 2025, the cargo throughput of Guangxi Beibu Gulf Port is expected to exceed 400 million tons, and the container throughput is expected to exceed 10 million TEU.

Second, the cargo throughput and container throughput of the Qinzhou port area will maintain rapid growth. By 2025, the cargo throughput of Qinzhou port area is expected to exceed 220 million tons, and the container throughput is expected to reach 8 million TEU. The increase of the cargo throughput and container throughput of Qinzhou port area will directly determine the overall throughput of Guangxi Beibu Gulf Port, Qinzhou port area become the core port area of Guangxi Beibu Gulf Port.

Third, the cargo throughput and container throughput of the Beihai port area will also maintain the growth trend. By 2025, the cargo throughput of Beihai port area is expected to exceed 45 million tons and the container throughput is expected to reach 1 million TEU.

Fourth, the cargo throughput and container throughput of Fangcheng port area will also maintain a growth trend. By 2025, the cargo throughput of Fangcheng port area is expected to exceed 150 million tons and the container throughput is expected to reach 1.3 million TEU.

The above results predicted by the weighted moving average forecasting method have a good fitting trend, which can provide data support for the planning and construction of Guangxi Beibu Gulf Port. However, this method considers a single influence factor, and more factors affecting the development of Guangxi Beibu Gulf Port can be considered in the course of future study. A new forecasting model of cargo throughput and container throughput is established by using multiple regression or BP neural network. Compared with the weighted moving average forecasting method, a better forecasting model is selected.

In view of the above conclusions, the following measures can be taken to strengthen the sustainable development of Guangxi Beibu Gulf Port.

First, strengthening the construction of Guangxi Beibu Gulf Port to rationally plan the functions of each port area of Guangxi Beibu Gulf Port by integrating resources and division and cooperate. Strengthen the construction of bulk cargo terminals such as coal, ore, sulfur and grain in Fangcheng prot area, strengthening the construction of international container hub ports in Qinzhou port area, and speed up the construction of industrial supporting functions such as petrochemical, forest pulp and paper in Beihai port area. Strengthen infrastructure development such as ports, berths, loading, and unloading facilities and equipment. Strengthen the informatization and intelligentization of port operation, especially the construction of the fully intelligent container terminal in Qinzhou port area. Speed up the improvement of port services.

Second, strengthen the coordinated development of Guangxi Beibu Gulf Port and its economic hinterland. Vigorously develop the port industry in Fangcheng, Qinzhou and Beihai port areas, and promote the integrated development of the port and city. In particular, strengthen investment promotion in Qinzhou area of Guangxi Free Trade Zone and connect Qinzhou urban area with the new port city. Accelerate the construction of Beihai Tieshan port area to build a new industrial city. Strengthen co-operation with other cities in Guangxi region, accelerate the construction of the Pinglu Canal. Realize river-sea combined transportation at an early date, and enrich the supply of goods at coastal ports. Strengthen cooperation with

GATR Global J. Bus. Soc. Sci. Review 9 (1) 73 - 89 (2021) 
Chongqing, Sichuan, Yunnan, Guizhou, Gansu, Xinjiang, and other western provinces in the construction of Western Land-Sea New Passage in China. Attract goods from all provinces along the Belt and Road to Guangxi ports, and introduce high-quality enterprises from all provinces along the Road to invest and develop Guangxi. Strengthen cooperation with major ASEAN countries represented by Singapore, expand overseas imports, exports, and transit of goods, and expand the scale of foreign investment utilization.

Third, accelerate the construction of the port collection and distribution system. Strengthen the construction of railways and expressways in and out of Fangcheng, Qinzhou and Beihai port areas. Actively promote the construction of the eastern, central and western railway lines of the Western Land-sea new passages in the west of China, especially speed up the construction of the Huangtong-Baise railway between Guizhou and Guangxi, and the upgrading and renovation of the Qian-Gui railway and the Huai-Liu railway. Support port-related logistics enterprises to become bigger and stronger.

Fourth, cultivate and introduce high-quality talents of various port logistics. Strengthen the cooperation with colleges and universities in the area and cultivate various talents that are urgently needed in port logistics. Introduce excellent port operation and management talents from outside the region and even from abroad.

\section{Acknowledgments}

This work is supported by the fund for cultivating young and middle-aged academic leaders of Guangxi University of Finance and Economics. And supported by the "Big Data + Emergency Logistics" team, the second innovation team of Guangxi University of Finance and Economics. The paper is also supported by the Management Science and Engineering discipline construction fund of Guangxi University of Finance and Economics.

\section{References}

Ajzen, I. (1991). The theory of planned behavior. Organizational behavior and human decision processes, 50(2), 179211. http://doi.org/10.1016/0749-5978(91)90020-T

Bamberg, S., \& Möser, G. (2007). Twenty years after Hines, Hungerford, and Tomera: A new meta-analysis of psychosocial determinants of pro-environmental behaviour. Journal of environmental psychology, 27(1), 14-25. https://doi.org/10.1016/j.jenvp.2006.12.002

Brown, S., Pyke, D., \& Steenhof, P. (2010). Electric vehicles: The role and importance of standards in an emerging market. Energy Policy, 38(7), 3797-3806. https://doi.org/10.1016/j.enpol.2010.02.059

Buekers, J., Van Holderbeke, M., Bierkens, J., \& Panis, L. I. (2014). Health and environmental benefits related to electric vehicle introduction in EU countries. Transportation Research Part D: Transport and Environment, 33, 2638.https://doi.org/10.1016/j.trd.2014.09.002

Du, J., \& Ouyang, D. (2017). Progress of Chinese electric vehicles industrialization in 2015: A review. Applied Energy, 188, 529-546.https://doi.org/10.1016/j.apenergy.2016.11.129

Fryxell, G. E., \& Lo, C. W. (2003). The influence of environmental knowledge and values on managerial behaviours on behalf of the environment: An empirical examination of managers in China. Journal of business ethics, 46(1), 45-69. http://doi.org/10.1023/A:1024773012398

Henning, O., \& Karlsson, S. (2011). Environmental attitudes and how they affect purchase intentions of environmentally friendly automobiles: An emperical study on Chinese students at Jönköping University.

Yusof, J. M., Singh, G. K. B., \& Razak, R. A. (2013). Purchase intention of environment-friendly automobile. ProcediaSocial and Behavioral Sciences, 85, 400-410. https://doi.org/10.1016/j.sbspro.2013.08.369

IEA World Energy Outlook. (2006). International Energy Agency: Paris, France. https://doi.org/10.1787/weo2006-en

Kaiser, F. G., Ranney, M., Hartig, T., \& Bowler, P. A. (1999). Ecological behavior, environmental attitude, and feelings of responsibility for the environment. European psychologist, 4(2), 59.http://doi.org/10.1027//1016-9040.4.2.59

Kim, H. S., \& Damhorst, M. L. (1998). Environmental concern and apparel consumption. Clothing and Textiles Research Journal, 16(3), 126-133. https://doi.org/10.1177\%2F0887302X9801600303 
Kollmuss, A., \& Agyeman, J. (2002). Mind the gap: why do people act environmentally and what are the barriers to pro-environmental behavior?. Environmental education research, 8(3), 239-260. https://doi.org/10.1080/13504620220145401

Latif, S. A., Omar, M. S., Bidin, Y. H., \& Awang, Z. (2018). Analyzing the effect of situational factor on recycling behaviour in determining the quality of life. Journal of Asian Behavioural Studies, 3(6), 11-17. http://doi.org/10.21834/jabs.v3i6.231

Lesemann, M., Welfers, T., \& Eckstein, L. (2012). Development of a Fully Electric Light Duty Vehicle-The DELIVER Project. Procedia-Social and Behavioral Sciences, 48, 553-569.https://doi.org/10.1016/j.sbspro.2012.06.1034

Lou, Y., Wang, W., \& Yang, X. (2017). Customers' attitude on new energy vehicles' policies and policy impact on customers' purchase intention. Energy Procedia, 105, 2187-2193.https://doi.org/10.1016/j.egypro.2017.03.617

Moons, I., \& De Pelsmacker, P. (2012). Emotions as determinants of electric car usage intention. Journal of Marketing Management, 28(3-4), 195-237. http://doi.org/10.1080/0267257X.2012.659007

Moyo, N., \& Masuku, F. (2018). Based on Environmental Education: The Effects of Environmental Knowledge and Awareness on the Purchase Intention of New Energy Vehicles in the Southern part of China. Advances in Social Sciences Research Journal, 5(11) 390- 402. https://doi.org/10.14738/assrj.511.5405

Onat, N. C., Kucukvar, M., Aboushaqrah, N. N., \& Jabbar, R. (2019). How sustainable is electric mobility? A comprehensive sustainability assessment approach for the case of Qatar. Applied Energy, 250, 461-477. https://doi.org/10.1016/j.apenergy.2019.05.076

Poullikkas, A. (2015). Sustainable options for electric vehicle technologies. Renewable and Sustainable Energy Reviews, 41, 1277-1287.https://doi.org/10.1016/j.rser.2014.09.016

Rezvani, Z., Jansson, J., \& Bodin, J. (2015). Advances in consumer electric vehicle adoption research: A review and research agenda. Transportation research part D: transport and environment, 34, 122-136. https://doi.org/10.1016/j.trd.2014.10.010

Rogers, E. M., (2003).Diffusion of Innovations fifth Ed Free Press. New York. In Rezvani, Z., Jansson, J. \& Bodin, J. (2015). Advances in consumer electric vehicle adoption research: A review and research agenda. Transport Research Part D, 34, 122-136. https://doi.org/10.1016/j.trd.2014.10.010

Latif, S. A., Bidin, Y. H., \& Awang, Z. (2013). Towards the Realization of Green Cities: The moderating role of the residents' education level. Procedia-Social and Behavioral Sciences, 85, 646-652. https://doi.org/10.1016/j.sbspro.2013.08.392

Schulte, I., Hart, D., \& Van der Vorst, R. (2004). Issues affecting the acceptance of hydrogen fuel. International Journal of Hydrogen Energy, 29(7), 677-685. http://doi.org/10.1016/j.ijhydene.2003.09.006

Sovacool, B. K. (2009). Rejecting renewables: The socio-technical impediments to renewable electricity in the United States. Energy Policy, 37(11), 4500-4513. https://doi.org/10.1016/j.enpol.2009.05.073

Steg, L., \& Vlek, C. (2009). Encouraging pro-environmental behaviour: An integrative review and research agenda. Journal of environmental psychology, 29(3), 309-317.https://doi.org/10.1016/j.jenvp.2008.10.004

Stern, P. C. (2000). New environmental theories: toward a coherent theory of environmentally significant behavior. Journal of social issues, 56(3), 407-424.https://doi.org/10.1111/0022-4537.00175

Rezvani, Z., Jansson, J., \& Bodin, J. (2015). Advances in consumer electric vehicle adoption research: A review and research agenda. Transportation research part D: transport and environment, 34, 122-136. https://doi.org/10.1016/j.trd.2014.10.010

Thomas, C. S. (2012). How green are electric vehicles?. International journal of hydrogen energy, 37(7), 6053-6062. https://doi.org/10.1016/j.ijhydene.2011.12.118

Ustaoğlu, M., \& Yıldız, B. (2012). Innovative Green TechnologyinTurkey: Electric Vehicles' Future and Forecasting Market Share. Procedia-Social and Behavioral Sciences, 41, 139-146. https://doi.org/10.1016/j.sbspro.2012.04.018 Williams, E., Das, V., \& Fisher, A. (2020). Assessing the Sustainability Implications of Autonomous Vehicles: Recommendations for Research Community Practice. Sustainability, 12(5), 1902.https://doi.org/10.3390/su12051902

Yusof, J. M., Singh, G. K. B., \& Razak, R. A. (2013). Purchase intention of environment-friendly automobile. ProcediaSocial and Behavioral Sciences, 85, 400-410.https://doi.org/10.1016/j.sbspro.2013.08.369 